\title{
GROWTH, YIELD AND QUALITY OF WHEAT VARITIES AS AFFECTED BY DIFFERENT LEVELS OF NITROGEN
}

\author{
H. Mondal ${ }^{1}$, S. Mazumder ${ }^{2}$, S. K. Roy ${ }^{3}$, T. A. Mujahidi ${ }^{4}$ and S. K. Paul ${ }^{5}$ \\ ${ }_{1}^{1}$ Department of Agronomy, Sher-e-Bangla Agricultural University, Dhaka-1207, Bangladesh \\ 2Sher-e-Bangla Nagar Adorsha Mohila College, Dhaka-1207, Bangladesh, \\ ${ }^{3}$ Department of Genetics and Plant Breeding, Sher-e-Bangla Agricultural University, Dhaka-1207, Bangladesh \\ ${ }^{4}$ Plant Breeding Division, Bangladesh Agricultural Research Institute, Joydebpur, Gazipur-1701, Bangladesh \\ ${ }^{5}$ Agronomy Division, Bangladesh Agricultural Research Institute, Joydebpur, Gazipur-1701, Bangladesh. \\ E-mail: kbdhimangshu88@gmail.com
}

Key Words: Wheat variety, Nitrogen, Protein, Grain quality

\begin{abstract}
A field experiment was conducted at the experimental field of Sher-e-Bangla Agricultural University, Dhaka, Bangladesh during November 2012 to March 2013 to evaluate the response of three (3) wheat varieties viz., BARI Gom23, BARI Gom24 and BARI Gom25 under four levels of nitrogen fertilizer i.e, 75, 100, 125 and $150 \mathrm{~kg}$ $\mathrm{N}$ ha ${ }^{-1}$. The experiment was laid out in Randomized Complete Block Design (RCBD) with three replications. Results showed that plant height, number of leaves plant ${ }^{-1}$, leaf length and dry matter content were significantly affected due to varieties and/or nitrogen levels. Grains ear-1, number of fertile grains plant ${ }^{-1}, 1000$-grain weight, grain yield and harvest index were also significantly influenced by varieties and/or nitrogen levels. The value of all parameters studied in this experiment increased with increasing nitrogen levels up to $125 \mathrm{~kg} \mathrm{~N} \mathrm{ha}^{-1}$ and thereafter decreased with fertilizer increasing level. Combination results showed that BARI Gom-24 with application of $125 \mathrm{~kg} \mathrm{~N} \mathrm{ha}-1$ gave the maximum grain yield ( $\left.4.71 \mathrm{t} \mathrm{ha}^{-1}\right)$, harvest index $(49.37 \%)$ and protein content (10.88\%).
\end{abstract}

\section{Introduction}

Wheat (Triticum aestivum L.) is the first important cereal crop throughout the world and second in Bangladesh. It is the leading cereal crop which ranks first both in area $(21,360$ thousand hectares) and production (5,76,317 thousand metric ton) of the world (FAO, 2014). It is a staple food for about one billion in as many as 43 countries and provides about 205 of total food calories. It contains carbohydrate (78.1\%), protein (14.7\%), minerals $(2.1 \%)$, fat $(2.1 \%)$ and considerable proportion of vitamins (Jahan. 2014). Wheat is cool-loving crop and adopted for cultivation in regions with cooler climatic conditions whereas Bangladesh lies in the warmer part of the world, however wheat is grown in the winter or cold season in Bangladesh from November to March. Although wheat is cultivated in a large area (0.453 million ha) in Bangladesh but the average yield (3.03 t ha $\left.{ }^{1}\right)$ of wheat is very low. The low yield of wheat may be due to various factors such as lack of varieties, good quality seed, untimely seedling, low fertilization, seed rate, sowing techniques etc. Balanced fertilization and better cultural practices are needed for obtaining higher yield of wheat. Nitrogen is one of the basic elements required for obtaining higher wheat yield. It is largely used in the synthesis of protein, chlorophyll and other vital compounds which are attributed to all physiological and biochemical processes of plants. The response to $\mathrm{N}$ fertilization varies according to location, climate, crops and their varieties, type and characteristics of the soil, rate, time of fertilizer application and its placement (Mengel and Kirkby, 1978). Unlike the other major plant nutrient elements, nitrogen is the 
most limiting one in most of the soils of Bangladesh for sustenance of optimum plant growth. Therefore, this nutrient is mostly added extraneously in order to supplement their deficiencies in soil for successful crop production. But the addition of nitrogen beyond optimum level affects plant performance adversely. On the other hand, nitrogen either as nitrate or ammonium form is very unstable in soil in its natural cycle. It is reported that split application of nitrogen is better than singles application for increasing yield of wheat (Gravelle et al., 1989). Top dressing and split application of nitrogen fertilizers at critical crop growth stages of wheat are now emphasized (Singh, 1988) as it is more beneficial than applying as single dose at sowing (Randhawa et al., 1976). However, the yield response varies with number of split and time of nitrogen application. Hence, it would be a good effort to develop an effective schedule for nitrogen management for wheat crop by the way of quantity split and time of application. Besides this, the quality of wheat is directly related to protein content. High grain protein level in wheat is an important consideration for human nutrition but the varieties grown in the country are of low to medium protein content (Warsthorn, 1988). High grain quality required a steady nutrient supply. Many authors have found that most of the nitrogen uptakement by wheat plants occur before anthesis (Dhugga and Waines, 1989; Frank et al., 1989). Hence, the application of nitrogenous fertilizer is important for increasing grain protein content of wheat. In Bangladesh, very little research work has been done on the effect of nitrogen application on wheat grain protein content and to acknowledge no work seems to have been reported on its relation with grain yield, as regards of in view of the limited information on the aforesaid problems a study was therefore, undertaken to determine the response of wheat variety as influenced by different levels of nitrogen.

\section{Materials and Methods}

The experiment was conducted at the agronomy field of Sher-e-Bangla Agricultural University, Dhaka-1207, during the period from November 2012 to March 2013. The experimental area is located at 23.41' $\mathrm{N}$ and 90.22 ' E latitude and at an altitude of $8.6 \mathrm{~m}$ from the sea level. The soil of the experimental field belongs to the Tejgaon series under the Agroecological Zone, Madhupur Tract (AEZ- 28) and the General Soil Type is Deep Red Brown Terrace Soils. The experiment was laid out in Randomized Complete Block Design (RCBD) with factorial arrangement and three replications. There are two sets of treatments in the experiment. Factor A: Variety (3), $\mathrm{V}_{1}=$ BARI Gom-23 (Bijoy), $\mathrm{V}_{2}=$ BARI Gom-24 (Prodip), $\mathrm{V}_{3}=$ BARI Gom-25 and Factor B: Nitrogen levels (4) $\mathrm{N}_{1}=75 \mathrm{~kg} \mathrm{~N} \mathrm{ha}{ }^{-1}, \mathrm{~N}_{2}=100 \mathrm{~kg} \mathrm{~N} \mathrm{ha}{ }^{-1} \mathrm{~N}_{3}=125 \mathrm{~kg} \mathrm{~N} \mathrm{ha}^{-1}$, $\mathrm{N}_{4}=150 \mathrm{~kg} \mathrm{~N} \mathrm{ha}{ }^{-1}$. There were 12 treatment combinations. Seeds were sown continuously in line on 19 November, 2012. The line to line distance was maintained at $20 \mathrm{~cm}$. The form of $\mathrm{N}$ fertilizer was granular urea. The experimental plots were fertilized with $\mathrm{P}, \mathrm{K}, \mathrm{S}$ and $\mathrm{B}$ at the rate of 26-50-20-1 kg ha-1, respectively in the form of triple superphosphate (TSP), muriate of potash (MOP), gypsum and boric acid, accordingly during final land preparation as basal dose. The fertilizer does was according to soil test basis. Here $\mathrm{K}$ application was high than $\mathrm{P}$ to improve the grain quality. One third of nitrogenous fertilizer was incorporated in the soil at the time of final land preparation according to treatments. The remaining amount of nitrogenous fertilizer was applied as top dressing in two split doses at crown root initiation stage (20 DAS) and prior to spike initiation stage (55 DAS). Two times weeding were done manually at 25 and 45 DAS. Two irrigations were applied at the time of crown root initiation stage (20 DAS) and booting stage (55 DAS). Excess water was drained out from the field. All other intercultural operations were done as per requirement. The crop was harvested on March 18, 2013. The necessary data were collected from ten selected plants from each plot in the field at 30 days interval and at harvest, and dry matter weight of plant was collected at 30 days interval from 
Growth, Yield and Quality of Wheat Varities as Affected by Different Levels of Nitrogen

the sub-samples of 5 plants plot ${ }^{-1}$ uprooting from 2 nd line and were oven dried until a constant level. Final yield data were collected from undisturbed middle three rows in the center. The data obtained for different characters were statistically analyzed following the analysis of variance techniques by using MSTAT-C computer package programme. The significant differences among the treatment means were compared by least significant difference (LSD) at 5\% level of probability (Gomez and Gomez, 1984).

\section{Plant height}

\section{Results and Discussion}

Significant variation was recorded for plant height of wheat due to varieties at 90 DAS (Table 1 ). The tallest plants were observed from $V_{2}$, while the shortest plants were found in $V_{1}$. On the other hand, due to nitrogen plant height of wheat varied significantly at 90 DAS. At 90 DAS, the tallest plants were observed from $\mathrm{N}_{3}$ and the shortest plants were found in $\mathrm{N}_{1}$. Significant differences were also recorded for the interaction effect of varieties and nitrogen on plant height of wheat at 90 DAS. At 90 DAS, the tallest plants were observed from $\mathrm{V}_{2} \mathrm{~N}_{3}$ and the shortest) plants were found in $\mathrm{V}_{1} \mathrm{~N}_{1}$. Similar results were found by (Randhawa et al., 1976).

Table 1. Effect of variety, nitrogen rate and their combination on plant height of wheat

\begin{tabular}{|c|c|c|c|}
\hline \multirow[t]{2}{*}{ Treatment } & \multicolumn{3}{|c|}{ Plant height $(\mathrm{cm})$ at } \\
\hline & 30 DAS & 60 DAS & 90 DAS \\
\hline \multicolumn{4}{|c|}{ Variety } \\
\hline $\mathrm{V}_{1}$ & $30.58 c$ & $61.33 c$ & $90.79 c$ \\
\hline $\mathrm{V}_{2}$ & $37.17 \mathrm{a}$ & $69.14 \mathrm{a}$ & $95.85 \mathrm{a}$ \\
\hline $\mathrm{V}_{3}$ & $33.72 \mathrm{~b}$ & 65.39 b & $93.05 \mathrm{~b}$ \\
\hline $\operatorname{LSD}_{(0.05)}$ & 3.063 & 3.050 & 2.604 \\
\hline \multicolumn{4}{|c|}{ Nitrogen level } \\
\hline $\mathrm{N}_{1}$ & 35.33 & $63.37 \mathrm{~d}$ & $89.17 \mathrm{~d}$ \\
\hline $\mathrm{N}_{2}$ & 34.89 & $66.61 \mathrm{c}$ & $92.15 \mathrm{c}$ \\
\hline $\mathrm{N}_{3}$ & 38.33 & $72.78 \mathrm{a}$ & $98.77 \mathrm{a}$ \\
\hline $\mathrm{N}_{4}$ & 36.33 & $69.70 \mathrm{~b}$ & $95.20 \mathrm{~b}$ \\
\hline $\operatorname{LSD}_{(0.05)}$ & NS & 3.063 & 2.945 \\
\hline \multicolumn{4}{|c|}{ Variety x Nitrogen level } \\
\hline $\mathrm{V}_{1} \mathrm{~N}_{1}$ & $22.67 \mathrm{~h}$ & $57.78 \mathrm{i}$ & $82.18 \mathrm{~g}$ \\
\hline $\mathrm{V}_{1} \mathrm{~N}_{2}$ & $32.67 \mathrm{f}$ & $60.89 \mathrm{~h}$ & 92.14 ef \\
\hline $\mathrm{V}_{1} \mathrm{~N}_{3}$ & $32.67 \mathrm{f}$ & $65.45 e$ & $93.18 \mathrm{de}$ \\
\hline $\mathrm{V}_{1} \mathrm{~N}_{4}$ & $33.33 e$ & $63.00 \mathrm{~g}$ & $91.76 \mathrm{f}$ \\
\hline $\mathrm{V}_{2} \mathrm{~N}_{1}$ & $34.67 \mathrm{~d}$ & $68.33 c$ & $93.17 \mathrm{de}$ \\
\hline $\mathrm{V}_{2} \mathrm{~N}_{2}$ & $40.67 \mathrm{~b}$ & $67.55 \mathrm{~d}$ & $96.04 \mathrm{~b}$ \\
\hline $\mathrm{V}_{2} \mathrm{~N}_{3}$ & $42.00 \mathrm{a}$ & $72.45 \mathrm{a}$ & $99.85 \mathrm{a}$ \\
\hline $\mathrm{V}_{2} \mathrm{~N}_{4}$ & $34.33 \mathrm{~d}$ & $70.22 \mathrm{~b}$ & $94.12 \mathrm{~d}$ \\
\hline $\mathrm{V}_{3} \mathrm{~N}_{1}$ & $38.67 \mathrm{c}$ & $67.67 \mathrm{~d}$ & 92.14 ef \\
\hline $\mathrm{V}_{3} \mathrm{~N}_{2}$ & $31.67 \mathrm{~g}$ & $67.22 \mathrm{de}$ & $95.41 \mathrm{c}$ \\
\hline $\mathrm{V}_{3} \mathrm{~N}_{3}$ & $32.67 \mathrm{f}$ & $63.00 \mathrm{~g}$ & $93.74 \mathrm{~d}$ \\
\hline $\mathrm{V}_{3} \mathrm{~N}_{4}$ & $32.67 \mathrm{f}$ & $63.89 \mathrm{f}$ & $93.43 \mathrm{~d}$ \\
\hline $\operatorname{LSD}_{(0.05)}$ & 0.126 & 0.341 & 1.208 \\
\hline CV (\%) & 7.59 & 4.32 & 5.94 \\
\hline
\end{tabular}

In a column means having similar letter (s) are statistically similar and those having dissimilar letter(s) differ significantly by LSD at 0.05 levels of probability

$\mathrm{V}_{1}$-BARI Gom-23, V ${ }_{2}$-BARI Gom-24 and V $\mathrm{V}_{3}$-BARI Gom-25, $\mathrm{N}_{1}-75 \mathrm{~kg} \mathrm{~N}$ ha-1 $\mathrm{N}_{2}-100 \mathrm{~kg} \mathrm{~N} \mathrm{ha-1}, \mathrm{N}_{3}-125 \mathrm{~kg} \mathrm{~N}$ ha $^{-1}$ and $\mathrm{N}_{4}-150 \mathrm{~kg} \mathrm{~N} \mathrm{ha}{ }^{-1}$. 
Mondal et al.

\section{Number of leaves per plant}

Statistically significant differences were recorded for number of leaves plant ${ }^{-1}$ of wheat due to different varieties. At $90 \mathrm{DAS}$, the maximum number of leaves plant ${ }^{-1}$ was found from $\mathrm{V}_{2}$ and the minimum number of leaves plant ${ }^{-1}$ was observed from $V_{1}$ (Table 2). Different nitrogen levels were significantly affect on number of leaves plant ${ }^{-1}$ of wheat at 90 DAS and the highest (number of leaves plant ${ }^{-1}$ was recorded from $\mathrm{N}_{3}$ whereas, the lowest number of leaves plant ${ }^{-1}$ was found from $\mathrm{N}_{1}$ (Table 2). Significant variation was also recorded due to combined effect of varieties and different nitrogen levels in terms of number of leaves plant ${ }^{-1}$ of wheat at 90 DAS and the maximum number of leaves plant ${ }^{-1}$ was observed from $\mathrm{V}_{2} \mathrm{~N}_{3}$ whereas, the lowest number of leaves plant ${ }^{-1}$ was found from $\mathrm{V}_{1} \mathrm{~N}_{1}$.

Table 2. Effect of variety, nitrogen rate and their combination on number of leaves plant ${ }^{-1}$ of wheat

\begin{tabular}{|c|c|c|c|}
\hline \multirow[t]{2}{*}{ Treatment } & \multicolumn{3}{|c|}{ Number of leaves plant ${ }^{-1}$ at } \\
\hline & 30 DAS & 60 DAS & 90 DAS \\
\hline \multicolumn{4}{|c|}{ Variety } \\
\hline $\mathrm{V}_{1}$ & $3.03 \mathrm{c}$ & $3.08 \mathrm{c}$ & $3.11 \mathrm{c}$ \\
\hline $\mathrm{V}_{2}$ & $5.03 \mathrm{a}$ & 5.14 a & $5.17 \mathrm{a}$ \\
\hline $\mathrm{V}_{3}$ & $4.08 \mathrm{~b}$ & $4.09 \mathrm{~b}$ & $4.22 \mathrm{~b}$ \\
\hline $\operatorname{LSD}_{(0.05)}$ & 0.4421 & 0.2172 & 0.1709 \\
\hline \multicolumn{4}{|c|}{ Nitrogen level } \\
\hline $\mathrm{N}_{1}$ & $3.11 \mathrm{c}$ & $3.56 \mathrm{~d}$ & $4.00 \mathrm{~d}$ \\
\hline $\mathrm{N}_{2}$ & $4.01 \mathrm{~b}$ & $4.40 \mathrm{~b}$ & $4.62 \mathrm{~b}$ \\
\hline $\mathrm{N}_{3}$ & $5.00 \mathrm{a}$ & $5.11 \mathrm{a}$ & $5.15 \mathrm{a}$ \\
\hline $\mathrm{N}_{4}$ & $4.03 \mathrm{~b}$ & $4.07 \mathrm{c}$ & $4.15 c$ \\
\hline $\operatorname{LSD}_{(0.05)}$ & 0.8270 & 0.1930 & 0.2895 \\
\hline \multicolumn{4}{|c|}{ Variety x Nitrogen level } \\
\hline $\mathrm{V}_{1} \mathrm{~N}_{1}$ & $2.67 \mathrm{j}$ & $3.00 \mathrm{f}$ & $3.02 \mathrm{i}$ \\
\hline $\mathrm{V}_{1} \mathrm{~N}_{2}$ & $3.00 \mathrm{i}$ & $3.11 e$ & $3.21 \mathrm{~g}$ \\
\hline $\mathrm{V}_{1} \mathrm{~N}_{3}$ & $3.34 \mathrm{~g}$ & $3.11 e$ & $3.20 \mathrm{~g}$ \\
\hline $\mathrm{V}_{1} \mathrm{~N}_{4}$ & $3.11 \mathrm{~h}$ & $3.11 e$ & $3.11 \mathrm{~h}$ \\
\hline $\mathrm{V}_{2} \mathrm{~N}_{1}$ & $4.64 \mathrm{~d}$ & $5.04 \mathrm{~b}$ & $5.11 \mathrm{c}$ \\
\hline $\mathrm{V}_{2} \mathrm{~N}_{2}$ & $5.20 \mathrm{~b}$ & $5.05 \mathrm{~b}$ & $5.22 \mathrm{~b}$ \\
\hline $\mathrm{V}_{2} \mathrm{~N}_{3}$ & $5.31 \mathrm{a}$ & $5.35 \mathrm{a}$ & $5.45 \mathrm{a}$ \\
\hline $\mathrm{V}_{2} \mathrm{~N}_{4}$ & $4.97 \mathrm{c}$ & $5.05 \mathrm{~b}$ & $5.11 \mathrm{c}$ \\
\hline $\mathrm{V}_{3} \mathrm{~N}_{1}$ & $4.05 \mathrm{f}$ & $4.11 \mathrm{c}$ & $4.11 e$ \\
\hline $\mathrm{V}_{3} \mathrm{~N}_{2}$ & $4.05 \mathrm{f}$ & $4.11 \mathrm{c}$ & $4.00 \mathrm{f}$ \\
\hline $\mathrm{V}_{3} \mathrm{~N}_{3}$ & $4.16 e$ & $4.00 \mathrm{~d}$ & $4.11 e$ \\
\hline $\mathrm{V}_{3} \mathrm{~N}_{4}$ & $4.15 e$ & $4.11 \mathrm{c}$ & $4.33 \mathrm{~d}$ \\
\hline $\operatorname{LSD}_{(0.05)}$ & 0.043 & 0.045 & 0.041 \\
\hline $\mathrm{CV}(\%)$ & 2.49 & 5.93 & 3.20 \\
\hline
\end{tabular}

In a column means having similar letter (s) are statistically similar and those having dissimilar letter(s) differ significantly by LSD at 0.05 levels of probability

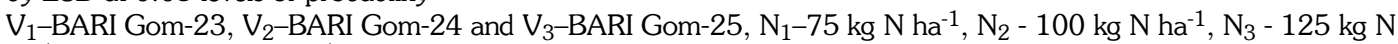
ha $^{-1}$ and $\mathrm{N}_{4}-150 \mathrm{~kg} \mathrm{~N} \mathrm{ha}^{-1}$. 
Growth, Yield and Quality of Wheat Varities as Affected by Different Levels of Nitrogen

\section{Leaf length $(\mathrm{cm})$}

Statistically significant differences were recorded for leaf length due to different wheat varieties and different level of nitrogenous fertilizer and also for the combination of variety and different nitrogen rate at 90 DAS (Table 3). The highest leaf length was found from $V_{2}$ and the lowest leaf length was observed from $V_{1}$ while due to the application of different dose of nitrogen the highest leaf length were observed from $\mathrm{N}_{3}$ whereas, the shortest leaf length was found from $\mathrm{N}_{1}$ and due to the combined effect of varieties and nitrogen the maximum leaf length were observed from $V_{2} N_{3}$ whereas, the lowest were found from $V_{1} N_{1}$.

Table 3. Effect of variety, nitrogen rate and their combination on leaf length of wheat

\begin{tabular}{|c|c|c|c|}
\hline \multirow[t]{2}{*}{ Treatment } & \multicolumn{3}{|c|}{ Leaf length $(\mathrm{cm})$ at } \\
\hline & 30 DAS & 60 DAS & 90 DAS \\
\hline \multicolumn{4}{|c|}{ Variety } \\
\hline $\mathrm{V}_{1}$ & $19.96 \mathrm{c}$ & $26.24 \mathrm{c}$ & $28.43 \mathrm{c}$ \\
\hline $\mathrm{V}_{2}$ & $23.72 \mathrm{a}$ & $30.25 \mathrm{a}$ & $31.22 \mathrm{a}$ \\
\hline $\mathrm{V}_{3}$ & $21.53 \mathrm{~b}$ & $28.33 \mathrm{~b}$ & $30.03 \mathrm{~b}$ \\
\hline $\operatorname{LSD}_{(0.05)}$ & 1.209 & 1.844 & 1.111 \\
\hline \multicolumn{4}{|c|}{ Nitrogen level } \\
\hline $\mathrm{N}_{1}$ & $21.82 \mathrm{c}$ & $26.92 \mathrm{c}$ & $27.13 \mathrm{c}$ \\
\hline $\mathrm{N}_{2}$ & $23.20 \mathrm{~b}$ & $28.52 \mathrm{~b}$ & $29.44 b$ \\
\hline $\mathrm{N}_{3}$ & $24.30 \mathrm{a}$ & $29.92 \mathrm{a}$ & $31.44 \mathrm{a}$ \\
\hline $\mathrm{N}_{4}$ & $23.04 \mathrm{~b}$ & $28.55 \mathrm{~b}$ & $29.22 \mathrm{~b}$ \\
\hline $\operatorname{LSD}_{(0.05)}$ & 1.076 & 1.273 & 1.630 \\
\hline \multicolumn{4}{|c|}{ Variety x Nitrogen level } \\
\hline $\mathrm{V}_{1} \mathrm{~N}_{1}$ & $17.06 j$ & $25.67 \mathrm{i}$ & $26.71 \mathrm{~h}$ \\
\hline $\mathrm{V}_{1} \mathrm{~N}_{2}$ & $20.11 \mathrm{~h}$ & $27.33 \mathrm{f}$ & $28.52 \mathrm{f}$ \\
\hline $\mathrm{V}_{1} \mathrm{~N}_{3}$ & $21.45 \mathrm{f}$ & $28.22 e$ & $29.84 \mathrm{~d}$ \\
\hline $\mathrm{V}_{1} \mathrm{~N}_{4}$ & $21.11 \mathrm{~g}$ & $26.22 \mathrm{~g}$ & $27.29 \mathrm{~g}$ \\
\hline $\mathrm{V}_{2} \mathrm{~N}_{1}$ & $22.78 \mathrm{c}$ & $31.11 \mathrm{~b}$ & $31.90 \mathrm{~b}$ \\
\hline $\mathrm{V}_{2} \mathrm{~N}_{2}$ & $24.22 \mathrm{~b}$ & $28.78 \mathrm{~d}$ & $29.26 \mathrm{~d}$ \\
\hline $\mathrm{V}_{2} \mathrm{~N}_{3}$ & $24.78 \mathrm{a}$ & $32.33 \mathrm{a}$ & $32.51 \mathrm{a}$ \\
\hline $\mathrm{V}_{2} \mathrm{~N}_{4}$ & $21.89 e$ & $31.00 \mathrm{~b}$ & $31.11 \mathrm{c}$ \\
\hline $\mathrm{V}_{3} \mathrm{~N}_{1}$ & $22.56 \mathrm{c}$ & $28.22 e$ & $28.45 \mathrm{f}$ \\
\hline $\mathrm{V}_{3} \mathrm{~N}_{2}$ & $22.22 \mathrm{~d}$ & $27.00 \mathrm{f}$ & $29.23 e$ \\
\hline $\mathrm{V}_{3} \mathrm{~N}_{3}$ & $17.89 \mathrm{i}$ & $29.55 c$ & $31.73 \mathrm{~b}$ \\
\hline $\mathrm{V}_{3} \mathrm{~N}_{4}$ & $21.00 \mathrm{~g}$ & $29.11 \mathrm{c}$ & $30.71 \mathrm{c}$ \\
\hline $\operatorname{LSD}_{(0.05)}$ & 0.418 & 0.688 & 0.223 \\
\hline CV (\%) & 7.49 & 7.03 & 3.40 \\
\hline
\end{tabular}

In a column means having similar letter (s) are statistically similar and those having dissimilar letter(s) differ significantly by LSD at 0.05 levels of probability

$V_{1}$-BARI Gom-23, V $V_{2}$-BARI Gom-24 and V $\mathrm{V}_{3}$-BARI Gom-25, $\mathrm{N}_{1}-75 \mathrm{~kg} \mathrm{~N}^{-1}, \mathrm{~N}_{2}-100 \mathrm{~kg} \mathrm{~N} \mathrm{ha}^{-1}, \mathrm{~N}_{3}-125 \mathrm{~kg} \mathrm{~N}$ ha ${ }^{-1}$ and $\mathrm{N}_{4}-150 \mathrm{~kg} \mathrm{~N}^{-1}$.

\section{Dry matter content $\left(\mathrm{g}\right.$ plant $\left.^{-1}\right)$}

Significant differences were recorded for dry matter content in plant of wheat due to different varieties and nitrogen levels, and also due to their combination effect at 90 DAS (Table 4). The maximum total dry matter in wheat plant were recorded from $\mathrm{V}_{2}$, whereas the lowest were in 
Mondal et al.

$\mathrm{V}_{1}$ On the other hand at 90 DAS, the highest dry matter in plant were recorded from $\mathrm{N}_{3}$, whereas the lowest were found in $\mathrm{N}_{1}$. In case of combination effect the highest dry matter were observed from $V_{2} \mathrm{~N}_{3}$, whereas the lowest were found in $\mathrm{V}_{1} \mathrm{~N}_{1}$.

Table 4. Effect of variety, nitrogen rate and their combination on weight of dry matter ( $\mathrm{g}$ plant $^{-1}$ ) of wheat

\begin{tabular}{|c|c|c|c|}
\hline \multirow[t]{2}{*}{ Treatment } & \multicolumn{3}{|c|}{ Dry matter (g plant $\left.{ }^{-1}\right)$ at } \\
\hline & 30 DAS & 60 DAS & 90 DAS \\
\hline \multicolumn{4}{|c|}{ Variety } \\
\hline $\mathrm{V}_{1}$ & $2.04 \mathrm{c}$ & $9.33 c$ & $12.79 \mathrm{c}$ \\
\hline $\mathrm{V}_{2}$ & $3.98 \mathrm{a}$ & $12.14 \mathrm{a}$ & $17.85 \mathrm{a}$ \\
\hline $\mathrm{V}_{3}$ & $2.79 \mathrm{~b}$ & $10.39 \mathrm{~b}$ & $14.05 \mathrm{~b}$ \\
\hline $\operatorname{LSD}_{(0.05)}$ & 0.103 & 1.050 & 1.627 \\
\hline \multicolumn{4}{|c|}{ Nitrogen level } \\
\hline $\mathrm{N}_{1}$ & $2.33 \mathrm{~d}$ & $7.37 \mathrm{~d}$ & $13.17 \mathrm{~d}$ \\
\hline $\mathrm{N}_{2}$ & $2.89 \mathrm{c}$ & $9.31 \mathrm{c}$ & $14.15 \mathrm{c}$ \\
\hline $\mathrm{N}_{3}$ & $4.33 \mathrm{a}$ & $11.78 \mathrm{a}$ & $17.77 \mathrm{a}$ \\
\hline $\mathrm{N}_{4}$ & $3.33 \mathrm{~b}$ & $10.60 \mathrm{~b}$ & $15.20 \mathrm{~b}$ \\
\hline $\operatorname{LSD}_{(0.05)}$ & 0.037 & 1.089 & 1.945 \\
\hline \multicolumn{4}{|c|}{ Variety x Nitrogen level } \\
\hline $\mathrm{V}_{1} \mathrm{~N}_{1}$ & $1.75 \mathrm{i}$ & $8.56 \mathrm{i}$ & $10.38 \mathrm{j}$ \\
\hline $\mathrm{V}_{1} \mathrm{~N}_{2}$ & $2.01 \mathrm{~h}$ & $9.19 \mathrm{~g}$ & $11.39 \mathrm{i}$ \\
\hline $\mathrm{V}_{1} \mathrm{~N}_{3}$ & $2.04 \mathrm{~h}$ & $10.38 e$ & $15.20 e$ \\
\hline $\mathrm{V}_{1} \mathrm{~N}_{4}$ & $2.34 \mathrm{gh}$ & $9.20 \mathrm{~g}$ & $13.79 \mathrm{~g}$ \\
\hline $\mathrm{V}_{2} \mathrm{~N}_{1}$ & $2.77 e f$ & $10.27 e$ & $15.70 e$ \\
\hline $\mathrm{V}_{2} \mathrm{~N}_{2}$ & $3.59 c$ & $11.39 e$ & $17.49 \mathrm{c}$ \\
\hline $\mathrm{V}_{2} \mathrm{~N}_{3}$ & $4.98 \mathrm{a}$ & $14.04 \mathrm{a}$ & $19.49 \mathrm{a}$ \\
\hline $\mathrm{V}_{2} \mathrm{~N}_{4}$ & $3.74 \mathrm{~b}$ & $13.09 \mathrm{~b}$ & $18.67 \mathrm{~b}$ \\
\hline $\mathrm{V}_{3} \mathrm{~N}_{1}$ & $2.37 \mathrm{~g}$ & $8.97 \mathrm{~h}$ & $11.99 \mathrm{~h}$ \\
\hline $\mathrm{V}_{3} \mathrm{~N}_{2}$ & 2.79 ef & $9.59 \mathrm{f}$ & $14.30 \mathrm{f}$ \\
\hline $\mathrm{V}_{3} \mathrm{~N}_{3}$ & $3.04 \mathrm{~d}$ & $12.03 \mathrm{c}$ & $16.59 \mathrm{~d}$ \\
\hline $\mathrm{V}_{3} \mathrm{~N}_{4}$ & $2.85 e$ & $10.99 \mathrm{~d}$ & $13.29 \mathrm{~g}$ \\
\hline $\operatorname{LSD}_{(0.05)}$ & 0.028 & 0.292 & 0.638 \\
\hline CV (\%) & 1.94 & 1.20 & 1.38 \\
\hline
\end{tabular}

In a column means having similar letter (s) are statistically similar and those having dissimilar letter(s) differ significantly by LSD at 0.05 levels of probability

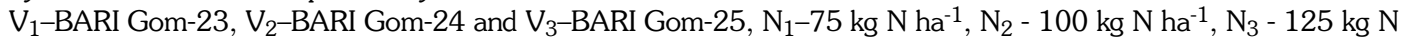
ha $^{-1}$ and $\mathrm{N}_{4}-150 \mathrm{~kg} \mathrm{~N}$ ha-

\section{Grains ear ${ }^{-1}$}

Number of grains ear ${ }^{-1}$ was significantly influenced by varieties, different nitrogen rate and also their combination (Table 5). The maximum grains ear-1 (17.47) in wheat plant was recorded from $V_{2}$, whereas the minimum (16.17) were found in $V_{1}$. Due to different nitrogen fertilizer application the maximum (17.60) grains ear ${ }^{-1}$ in wheat plant was recorded from $\mathrm{N}_{3}$, whereas the minimum (16.29) were found in $\mathrm{N}_{1}$. In case of combination effect the highest (18.24) grains ear ${ }^{-1}$ was observed from $V_{2} N_{3}$, whereas the lowest (15.57) were found in $V_{1} N_{1}$ 
Growth, Yield and Quality of Wheat Varities as Affected by Different Levels of Nitrogen

\section{Number of fertile grains plant ${ }^{-1}$}

Variation in fertile grains plant ${ }^{-1}$ among the studied varieties was statistically significant (Table 5). The highest (54.69) number of fertile grains plant ${ }^{-1}$ was observed in $V_{2}$ whereas, the lowest (45.55) was $V_{1}$. Results also showed that number of fertile grains plant ${ }^{-1}$ increased with increasing nitrogen levels and thereafter decreased by gradually increased the nitrogen levels. The highest (52.85) number of fertile grains plant ${ }^{-1}$ was recorded at $\mathrm{N}_{3}$ whereas, the lowest (48.63) was $\mathrm{N}_{1}$. The interaction effect of variety and nitrogen levels in relation to number of fertile grains plant ${ }^{-1}$ gave the highest (59.67) number of fertile grains plant ${ }^{-1}$ was observed in $\mathrm{V}_{2} \mathrm{~N}_{3}$ and the lowest (40.33) was recorded in $\mathrm{V}_{1} \mathrm{~N}_{1}$.

\section{Number of unfertile grains plant ${ }^{-1}$}

Variation in number of unfertile grains plant ${ }^{-1}$ among the studied varieties was statistically significant (Table 5). The highest (7.36) number of unfertile grains plant ${ }^{-1}$ was observed in $V_{1}$ whereas, the lowest (3.00) was recorded in $\mathrm{V}_{2}$. From Table 5 it is also observed that unfertile grains plant ${ }^{-1}$ decreased with increasing nitrogen and thereafter increased by gradually increased the nitrogen levels. The highest (6.45) unfertile grains plant ${ }^{-1}$ was observed $N_{1}$ and the lowest (5.63) number of unfertile grains plant ${ }^{-1}$ was recorded in $\mathrm{N}_{3}$. The interaction effect of different variety and nitrogen levels in relation to number of unfertile grains plant ${ }^{-1}$ was also statistically significant. The highest (7.89) number of unfertile grains plant ${ }^{-1}$ was observed in $\mathrm{V}_{1} \mathrm{~N}_{1}$ and the lowest (2.05) was recorded in $\mathrm{V}_{2} \mathrm{~N}_{3}$.

\section{0-grain weight}

A significant difference in 1000-grain weight was also observed in studied varieties of wheat. The highest (54.95 g) 1000-grain weight was recorded in $V_{2}$. In contrast, the lowest (50.91 g) 1000 -grain weight was recorded in $\mathrm{V}_{1}$. Genotypic variation in 1000-grain weight was also observed by many researchers in wheat (Ghosh et al., 1991; Bisht et al., 1999; Hassan, 2006; Chowdhury, 2008) that also conformity with the present experimental result. The highest (53.92 g) 1000-grain weight was recorded in $\mathrm{N}_{3}$ whereas, the lowest (49.82 g) 1000-grain weight was recorded in $\mathrm{N}_{1}$. In case of combination, the highest 1000-grain weight was recorded in $\mathrm{V}_{2} \mathrm{~N}_{3}(57.60 \mathrm{~g})$ whereas, the lowest $(48.97 \mathrm{~g}) 1000$-grain weight was recorded in $\mathrm{V}_{1} \mathrm{~N}_{1}$.

\section{Grain yield $\left(\mathrm{t} \mathrm{ha}^{-1}\right)$}

Variety had significant effect on grain yield of wheat (Table 5). The highest $\left(4.61 \mathrm{t} \mathrm{ha}^{-1}\right)$ grain yield was recorded in $V_{2}$ whereas; the lowest ( $3.45 \mathrm{t} \mathrm{ha}^{-1}$ ) was recorded from $V_{1}$. Nitrogen had also significant effect on grain of wheat. Results showed that grain yield increased with increasing nitrogen rate and thereafter decreased by gradually increased the nitrogen. The highest $\left(4.77 \mathrm{t} \mathrm{ha}^{-1}\right)$ grain yield was recorded in $\mathrm{N}_{3}$ whereas, the lowest $\left(3.20 \mathrm{t} \mathrm{ha}^{-1}\right)$ were recorded from $\mathrm{N}_{1}$. The interaction effect of variety and nitrogen on grain yield was significantly differ. In case of unit area, $\mathrm{V}_{2} \mathrm{~N}_{3}$ produced the highest $\left(4.71 \mathrm{t} \mathrm{ha}^{-1}\right)$ grain yield. In the interaction effect, $\mathrm{V}_{1} \mathrm{~N}_{1}$ was produced the lowest $\left(3.23 \mathrm{t} \mathrm{ha}^{-1}\right)$ grain yield.

\section{Straw yields $\left(\mathrm{t} \mathrm{ha}^{-1}\right)$}

The straw yield showed significant differences among the studied varieties (Table 5). BARI gom23 produced the highest $\left(5.92 \mathrm{t} \mathrm{ha}^{-1}\right)$ straw yield. On the other hand, BARI gom-24 produced the lowest straw yield $\left(5.02 \mathrm{t} \mathrm{ha}^{-1}\right)$. On the other hand the highest $\left(6.03 \mathrm{t} \mathrm{ha}^{-1}\right)$ straw yield was 
Mondal et al.

recorded in $\mathrm{N}_{1}$ whereas, the lowest $\left(4.83 \mathrm{t} \mathrm{ha}^{-1}\right)$ was recorded in $\mathrm{N}_{3}$. The interaction effect of variety and nitrogen in relation to straw yield was also significant. The highest $\left(6.11 \mathrm{t} \mathrm{ha}^{-1}\right)$ straw yield was observed in $\mathrm{V}_{1} \mathrm{~N}_{1}$ and the lowest (4.83t ha-1) was recorded in $\mathrm{V}_{2} \mathrm{~N}_{3}$.

\section{Harvest index (\%)}

Variation in harvest index among the studied varieties was statistically significant (Table 5). The highest (47.87 \%) HI was recorded in BARI Gom-24 whereas, the lowest (36.82 \%) harvest index was observed in BARI Gom-23. On the other hand in case of nitrogen rate the highest (49.68\%) HI recorded in $\mathrm{N}_{3}$ whereas, the lowest (34.67\%) harvest index was observed in $\mathrm{N}_{1}$. The interaction effect of variety and nitrogen in relation to $\mathrm{HI}$ was also statistically significant. Results showed that the highest (49.37\%) HI was found in $\mathrm{V}_{2} \mathrm{~N}_{3}$ and the lowest in $\mathrm{V}_{1} \mathrm{~N}_{1}(34.58$ $\%)$ due to the combination of variety and nitrogen dose.

Table 5. Effect of variety, nitrogen rate and their combination on yields and yield components of wheat

\begin{tabular}{|c|c|c|c|c|c|c|c|}
\hline Treatment & $\begin{array}{l}\text { Grains } \\
\text { ear }^{-1}\end{array}$ & $\begin{array}{l}\text { No. of } \\
\text { fertile } \\
\text { grains } \\
\text { plant }^{-1} \\
\end{array}$ & $\begin{array}{c}\text { No. of } \\
\text { unfertile } \\
\text { grains } \\
\text { plant }^{-1} \\
\end{array}$ & $\begin{array}{c}\text { 1000- } \\
\text { grain } \\
\text { weight (g) }\end{array}$ & $\begin{array}{c}\text { Grain } \\
\text { yield } \\
\left(\mathrm{t} \mathrm{ha}^{-1}\right)\end{array}$ & $\begin{array}{c}\text { Straw } \\
\text { yield } \\
\left(\mathrm{t} \mathrm{ha}^{-1}\right)\end{array}$ & $\begin{array}{c}\text { Harvest } \\
\text { index (\%) }\end{array}$ \\
\hline \multicolumn{8}{|c|}{ Variety } \\
\hline $\mathrm{V}_{1}$ & $16.17 \mathrm{c}$ & $45.55 \mathrm{c}$ & $7.36 \mathrm{a}$ & $50.91 \mathrm{c}$ & $3.45 c$ & $5.92 \mathrm{a}$ & $36.82 \mathrm{c}$ \\
\hline $\mathrm{V}_{2}$ & $17.47 \mathrm{a}$ & $54.69 \mathrm{a}$ & $3.00 \mathrm{c}$ & $54.95 \mathrm{a}$ & $4.61 \mathrm{a}$ & $5.02 \mathrm{c}$ & $47.87 \mathrm{a}$ \\
\hline $\mathrm{V}_{3}$ & $16.88 \mathrm{~b}$ & $49.83 \mathrm{~b}$ & $5.89 \mathrm{~b}$ & $52.47 \mathrm{~b}$ & $4.00 \mathrm{~b}$ & $5.32 \mathrm{~b}$ & $42.92 \mathrm{~b}$ \\
\hline $\mathrm{LSD}_{(0.05)}$ & 0.4941 & 3.994 & 1.488 & 1.529 & 0.5271 & 0.2798 & 3.945 \\
\hline \multicolumn{8}{|c|}{ Nitrogen level } \\
\hline $\mathrm{N}_{1}$ & $16.29 \mathrm{~d}$ & $48.63 \mathrm{c}$ & $6.45 \mathrm{a}$ & $49.82 \mathrm{~d}$ & $3.20 \mathrm{~d}$ & $6.03 \mathrm{a}$ & $34.67 \mathrm{~d}$ \\
\hline $\mathrm{N}_{2}$ & $16.81 \mathrm{c}$ & $51.89 \mathrm{~b}$ & $6.37 \mathrm{~b}$ & $51.59 \mathrm{c}$ & $4.10 \mathrm{c}$ & $5.67 \mathrm{~b}$ & $41.97 \mathrm{c}$ \\
\hline $\mathrm{N}_{3}$ & $17.60 \mathrm{a}$ & $52.85 \mathrm{a}$ & $5.63 \mathrm{~d}$ & $53.92 \mathrm{a}$ & $4.77 \mathrm{a}$ & $4.83 \mathrm{~d}$ & $49.68 \mathrm{a}$ \\
\hline $\mathrm{N}_{4}$ & $17.20 \mathrm{~b}$ & $52.07 \mathrm{~b}$ & $5.89 c$ & $52.90 \mathrm{~b}$ & $4.40 \mathrm{~b}$ & $5.24 \mathrm{c}$ & $45.64 \mathrm{~b}$ \\
\hline $\mathrm{LSD}_{(0.05)}$ & 0.2390 & 0.627 & 0.079 & 0.943 & 0.2703 & 0.3378 & 2.849 \\
\hline \multicolumn{8}{|c|}{ Variety $\mathrm{x}$ Nitrogen level } \\
\hline $\mathrm{V}_{1} \mathrm{~N}_{1}$ & $15.57 \mathrm{i}$ & $40.33 \mathrm{j}$ & $7.89 a$ & $48.97 \mathrm{j}$ & $3.23 \mathrm{j}$ & $6.11 \mathrm{a}$ & $34.58 \mathrm{j}$ \\
\hline $\mathrm{V}_{1} \mathrm{~N}_{2}$ & $17.22 \mathrm{~d}$ & $51.78 e$ & $7.11 \mathrm{~b}$ & $52.55 e$ & $3.53 \mathrm{i}$ & $5.39 \mathrm{f}$ & $39.57 \mathrm{f}$ \\
\hline $\mathrm{V}_{1} \mathrm{~N}_{3}$ & $16.15 \mathrm{f}$ & $43.33 \mathrm{i}$ & $7.11 \mathrm{~b}$ & $49.90 \mathrm{i}$ & $3.32 \mathrm{~g}$ & $5.84 \mathrm{c}$ & $36.25 \mathrm{~h}$ \\
\hline $\mathrm{V}_{1} \mathrm{~N}_{4}$ & $15.81 \mathrm{f}-\mathrm{h}$ & $45.44 \mathrm{~h}$ & $7.11 \mathrm{~b}$ & $50.00 \mathrm{~h}$ & $3.76 \mathrm{~h}$ & $5.91 \mathrm{~b}$ & $38.88 \mathrm{~g}$ \\
\hline $\mathrm{V}_{2} \mathrm{~N}_{1}$ & $16.74 e$ & $53.55 \mathrm{~cd}$ & $2.89 \mathrm{~g}$ & $56.84 \mathrm{~b}$ & $4.66 \mathrm{~b}$ & $5.61 e$ & $45.38 \mathrm{c}$ \\
\hline $\mathrm{V}_{2} \mathrm{~N}_{2}$ & $17.13 \mathrm{~d}$ & $54.00 \mathrm{~b}$ & $4.33 e$ & $53.20 \mathrm{~d}$ & $4.46 \mathrm{~d}$ & $4.95 \mathrm{~h}$ & $47.39 \mathrm{~b}$ \\
\hline $\mathrm{V}_{2} \mathrm{~N}_{3}$ & 17.75 bc & $59.67 \mathrm{a}$ & $2.05 \mathrm{~h}$ & $57.60 \mathrm{a}$ & $4.71 \mathrm{a}$ & $4.83 \mathrm{j}$ & $49.37 \mathrm{a}$ \\
\hline $\mathrm{V}_{2} \mathrm{~N}_{4}$ & $18.24 \mathrm{a}$ & $52.55 \mathrm{~d}$ & $3.00 \mathrm{f}$ & $52.59 e$ & $4.01 \mathrm{f}$ & $4.90 \mathrm{i}$ & $45.00 \mathrm{c}$ \\
\hline $\mathrm{V}_{3} \mathrm{~N}_{1}$ & $17.58 \mathrm{c}$ & $49.44 \mathrm{f}$ & $6.22 c$ & $50.93 \mathrm{~g}$ & $4.39 e$ & $5.80 \mathrm{c}$ & $43.08 \mathrm{~d}$ \\
\hline $\mathrm{V}_{3} \mathrm{~N}_{2}$ & $16.07 \mathrm{f}$ & $49.89 \mathrm{f}$ & $5.11 \mathrm{~d}$ & $51.57 \mathrm{f}$ & $4.58 \mathrm{c}$ & $5.78 \mathrm{~d}$ & $43.08 \mathrm{~d}$ \\
\hline $\mathrm{V}_{3} \mathrm{~N}_{3}$ & $17.95 b$ & $53.78 \mathrm{c}$ & $6.00 \mathrm{c}$ & $53.82 \mathrm{c}$ & $3.30 \mathrm{~g}$ & $5.73 \mathrm{~d}$ & $35.48 \mathrm{i}$ \\
\hline $\mathrm{V}_{3} \mathrm{~N}_{4}$ & $15.90 \mathrm{fg}$ & $46.55 \mathrm{~g}$ & $5.78 \mathrm{c}$ & $53.37 \mathrm{~d}$ & $3.81 \mathrm{~g}$ & $5.19 \mathrm{~h}$ & $42.33 e$ \\
\hline $\operatorname{LSD}_{(0.05)}$ & 0.288 & 0.988 & 0.575 & 0.557 & 0.054 & 0.060 & 1.03 \\
\hline CV (\%) & 3.74 & 2.09 & 5.40 & 4.03 & 9.47 & 7.29 & 5.40 \\
\hline
\end{tabular}

In a column means having similar letter (s) are statistically similar and those having dissimilar letter(s) differ significantly by LSD at 0.05 levels of probability

$V_{1}$-BARI Gom-23, V $V_{2}$-BARI Gom-24 and V $\mathrm{V}_{3}$-BARI Gom-25, $\mathrm{N}_{1}-75 \mathrm{~kg} \mathrm{~N} \mathrm{ha}^{-1}, \mathrm{~N}_{2}-100 \mathrm{~kg} \mathrm{~N} \mathrm{ha}^{-1}, \mathrm{~N}_{3}-125 \mathrm{~kg} \mathrm{~N}$ ha $^{-1}$ and $\mathrm{N}_{4}-150 \mathrm{~kg} \mathrm{~N}$ ha 
Growth, Yield and Quality of Wheat Varities as Affected by Different Levels of Nitrogen

\section{Protein content (\%)}

Variation in Protein (\%) among the studied varieties was statistically significant (Figure 1). The highest protein content was recorded in BARI Gom-24 (10.64 \%) whereas, the lowest protein content was observed in BARI Gom-23 (9.82\%)

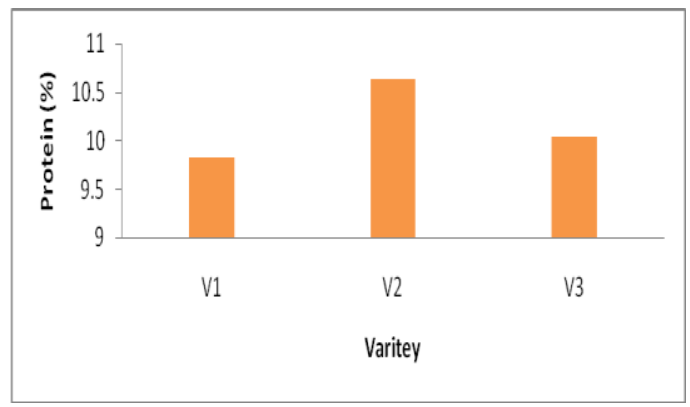

$\mathrm{V}_{1}=$ BARI Gom-23, $\mathrm{V}_{2}=$ BARI Gom- 24 and $\mathrm{V}_{3}=\mathrm{BARI}$ Gom-25.

Fig. 1. Effect of varieties on protein (\%) of wheat $\left(\mathrm{LSD}_{0.05}=0.0045\right)$

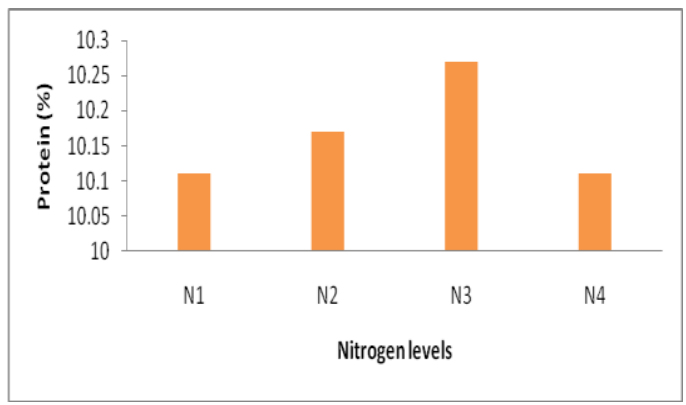

$\mathrm{N}_{1}=75 \mathrm{~kg} \mathrm{~N} \mathrm{ha}{ }^{-1}, \mathrm{~N}_{2}=100 \mathrm{~kg} \mathrm{~N} \mathrm{ha}{ }^{-1}, \mathrm{~N}_{3}-=125 \mathrm{~kg} \mathrm{~N}$ ha ${ }^{-1}$ and $\mathrm{N}_{4}=150 \mathrm{~kg} \mathrm{~N} \mathrm{ha}^{-1}$.

Fig.2. Effect of nitrogen on protein (\%) of wheat $\left(\mathrm{LSD}_{0.05}=0.0072\right)$

The effect of nitrogen on Protein (\%) was statistically significant (Figure 2). Result revealed that the highest $(10.27 \%)$ protein content recorded in $\mathrm{N}_{3}$ whereas, the lowest $(10.11 \%)$ protein was observed in $\mathrm{N}_{1}$.

The combination effect of variety and nitrogen in relation to protein (\%) was also statistically significant (Table 6). Results showed that the highest $(10.88 \%)$ protein was recorded in $\mathrm{V}_{2} \mathrm{~N}_{3}$ and the lowest (9.53\%) was in $\mathrm{V}_{1} \mathrm{~N}_{1}$.

Table 6. Combination effect of varieties and nitrogen on protein (\%) of wheat

\begin{tabular}{cc}
\hline Treatments & Protein (\%) \\
\hline $\mathrm{V}_{1} \mathrm{~N}_{1}$ & $9.53 \mathrm{e}$ \\
$\mathrm{V}_{1} \mathrm{~N}_{2}$ & $10.05 \mathrm{c}$ \\
$\mathrm{V}_{1} \mathrm{~N}_{3}$ & $10.54 \mathrm{~b}$ \\
$\mathrm{~V}_{1} \mathrm{~N}_{4}$ & $9.85 \mathrm{de}$ \\
$\mathrm{V}_{2} \mathrm{~N}_{1}$ & $10.05 \mathrm{c}$ \\
$\mathrm{V}_{2} \mathrm{~N}_{2}$ & $10.62 \mathrm{~b}$ \\
$\mathrm{~V}_{2} \mathrm{~N}_{3}$ & $10.88 \mathrm{a}$ \\
$\mathrm{V}_{2} \mathrm{~N}_{4}$ & $10.04 \mathrm{c}$ \\
$\mathrm{V}_{3} \mathrm{~N}_{1}$ & $9.89 \mathrm{c}-\mathrm{e}$ \\
$\mathrm{V}_{3} \mathrm{~N}_{2}$ & $9.81 \mathrm{e}$ \\
$\mathrm{V}_{3} \mathrm{~N}_{3}$ & $10.02 \mathrm{~cd}$ \\
$\mathrm{~V}_{3} \mathrm{~N}_{4}$ & $10.52 \mathrm{~b}$ \\
$\mathrm{LSD}$ & 0.1713 \\
$\mathrm{CV}(\%)$ & 4.38 \\
\hline
\end{tabular}

In a column means having similar letter (s) are statistically similar and those having dissimilar letter(s) differ significantly by LSD at 0.05 levels of probability

$\mathrm{V}_{1}$-BARI Gom-23, $\mathrm{V}_{2}$-BARI Gom-24 and $\mathrm{V}_{3}$-BARI Gom-25

$\mathrm{N}_{1}-75 \mathrm{~kg} \mathrm{~N} \mathrm{ha}^{-1}, \mathrm{~N}_{2}-100 \mathrm{~kg} \mathrm{~N} \mathrm{ha}{ }^{-1}, \mathrm{~N}_{3}-125 \mathrm{~kg} \mathrm{~N} \mathrm{ha}^{-1}$ and $\mathrm{N}_{4}-150 \mathrm{~kg} \mathrm{~N} \mathrm{ha}{ }^{-1}$. 


\section{Conclusion}

Based on the results of the study it can be concluded that cultivating BARI Gom-24 coupled with application of $125 \mathrm{~kg} \mathrm{~N} \mathrm{ha}{ }^{-1}$ will be a promising practice for good yield also for higher protein content of wheat. However, to reach a specific conclusion and recommendation, more research work on different varieties and rate of nitrogen should be done over different Agroecological zones.

\section{References}

Bisht, P. S., P. C. Pandey and P.Lal. 1999. Plant population requirement of wheat in the Tarai Region of Uttar Pradesh, India. Int. Rice Res. Notes. 24: 38.

Chowdhury, A. H. 2008. Effect of row spacing on morpho-physiological characters and yield of wheat. M. S Thesis, Dept. Crop Bot., Bangladesh Agric. Univ., Mymensingh.

Dhugga, S. C. and D. S. Waines 1989. Evaluation of fertilizer and seed rate in wheat (Triticum aestivum L.) under different tillage condition after transplanting rice (Oryza saliva). Indian J. Agril. Sci.70: 574-576.

FAO 2014. Statistic Yearbook. Food and Agriculture Organization, Rome, Italy.79: 23-34.

Frank, N. G., S. C. Dhugga and I. N. Frolov 1989. The role of sowing depth in the formation of spring wheat yield.Sibirskii vest selskokhozy aistvennoi NsukI 1:3-6.

Ghosh, B. C., C. V. Raghavain and M. K. Jana, 1991. Effect of spacing and nitrogen on growth and yield of wheat. Indian J. Agron. 36: 227-230.

Gomez, K. A. and A. A. Gomez 1984. Statistical procedure for agricultural research. Second Edn. Intl. Rice Res. Inst., John Wiley and Sons. New York. pp. 1-340.

Gravelle, A. S. M. H. M., A. Sufian, , J. M. Dxbury, J. G. Lauren, and C. A. Meinser 1989. Effect of tillage options and seed rate on grain yield of wheat. J. Subtrop. Agric. Res. Dev.2(3): 57-62.

Hassan, M. M. 2006. Effect of row spacing and weeding regime on the growth and yield of wheat. M. S. Thesis, Dept. Agron., Bangladesh Agril. Univ., Mymensingh. p. 42.

Jahan, M. A. H. S.. 2014.Effect of different weed control methods in wheat. Research report of wheat research centre.42-46.

Mengel, J. K. and Y. K. M. A. Kirkby. 1978. Effect of sowing density on yield, yield components and grain quality in new spring wheat lines and varieties. Biuletynlnstutui hodowli.44 (1 \& 4): 185-236.

Peterson, R. F. 1965. Wheat. Int. Sci. Pub. Inc., New York. p.258.

Randhawa, S. S., I., B. Pandey, and S. S. Mishra, 1976. Effect of organic manure, fertilizer level and seed rate on yield and quality of late sown wheat (Triticum aestivum L). Indian $\mathrm{J}$. Agron. 44(4): 754-759.

Razzaque, M. A. and A. B. S.Hossain. 1990. The wheat development programme in Bangladesh.Wheat for the non traditional warm areas. Proc: Intl. Conf. CIMMYT. Mexico. pp. 44-54.

Singh, C. S. and U. N. Singh. 2002. Effect of nitrogen and sulphur nutrition on growth and yield of rice (Oryza sativa L.) cultivars. Res. Crops. 3(3): 645-646.

Warsthorn, R. 1988. Comparative performance of different-sized grain derived from wheat seed. Am. J. Wheat Res. 63(5): 241-249. 